\title{
KNOWLEDGE MANAGEMENT IN THE PROJECT LIFE CYCLE - INITIAL RESEARCH ON POLISH SMES
}

\author{
Iwona ŁAPUŃKA ${ }^{*}$, Iwona PISZ ${ }^{* *}$ \\ * Opole University of Technology, Faculty of Production Engineering and Logistics, Opole, Poland \\ e-mail: i.lapunka@po.opole.pl \\ ${ }^{* *}$ Opole University, Faculty of Economics, Opole, Poland \\ e-mail: ipisz@uni.opole.pl
}

\begin{abstract}
Contemporary organizations run their activities in an environment, which might be defined as fully uncertain and turbulent. Due to variations that occur in the surrounding environment, an increased attention of management practitioners and theoreticians is paid to new management concepts frequently in an integrated version. The authors express a deep belief that consolidation of approaches to project management and knowledge management constitutes a response to challenge for modern organizations. Research into the issue was based on an attempt to determine significance of the knowledge management issue in a life of projects performed by Polish small and medium-sized enterprises (SMEs). Systemizing of desired knowledge management results in a project, from the point of view of its crucial success factors, is essentially substantiated in providing success of projects performed.

Preliminary research included SMEs in construction engineering industry. The enterprises perform project-driven orders or apply a project approach in economic activities that they execute. Research conducted by the authors so far, implies, that the SME sector is characterized by a particularly low efficiency in project management. Hypothetic assumptions indicate that one of the main reasons of reaching an unsatisfactory level of project proficiency shaped mainly by processes of synchronizing and coordination of project activities, is an insufficient level of development of social, organization and technological systems and methods of capitalization, as well as transmission of useful project management knowledge.

Essential function is performed by a group of selected respondents -25 enterprises from the group of SMEs, including 5 micro enterprises, 12 small enterprises, and 8 medium-sized enterprises. Analyses performed so far, take into consideration the economic situation of SMEs in Poland.
\end{abstract}

Keywords: project management, knowledge management, project life cycle, Polish SMEs sector, construction engineering industry.

\section{Introduction}

In conditions of progressing and global economic crisis, entrepreneurs search for new methods of development and remaining in the market of goods and services, and in marginal cases, the purpose constitutes a struggle for economic survival. It is necessary to introduce variations in the method of business activities running. An increasing uncertainty, resulting from fast variations imposes on the entrepreneurs a necessity to establish and implement new approaches to management in a company [38].

One of the methods includes introduction of solutions based on paradigms of project management into the enterprise practice. Project management techniques may be applied for efficient implementation of enterprise strategy. Project management constitutes an ap- propriate tool for implementation of quality improvement programs, as it creates a holistic approach to organization variations [43].

Introduction of a project management approach in an enterprise is particularly important for enterprises within the group of small and medium-sized enterprises (SMEs). SMEs sector constitutes a part of economy, which develops very dynamically. Companies that are included in the group of SMEs are able to react to variations in the market fastest - which involves the fact that they may easily adapt to it. Large economic entities are not so flexible. These conditions allow SMEs to act and develop actively in economic niche areas and in low-potential markets. Measures taken by companies from the SME sector contribute therefore to an increase in efficiency of the entire economy efficiency. 
Nevertheless, enterprises of this kind are sensitive to variations in the market, they are at risk of turbulences resulting from economic crisis. Change of a business activities running method, distinguishing of tasks in production system that are of routine type and tasks of unique type, the so-called projects, seems to be necessary. Process approach and project approach are significant from the point of view of market position maintenance of a given enterprise [16].

Knowledge management is analyzed usually in the context of permanent organizations, with constant organizations structure; however, there is a theoretical and empirical support for development of the field in the context of temporary organizations, such as project organizations [31]. Knowledge management in temporary organizations becomes an increasingly significant and even a decisive factor in the fight for competitive advantage [4].

Both areas of management science - knowledge management and project management become more and more frequently a subject of scientific research. Not much has been achieved so far in project knowledge management scope that is in a field, which links both the management concepts. Examining knowledge management in projects, it should be remembered that unique project features [40] imply different character of their management [41] and similarly, project knowledge management is somehow different from knowledge management in general.

The aim of the article is to present results of preliminary research conducted at a selected group of micro, SMEs in Opole Province, representing construction engineering industry. Particular attention has been paid to knowledge management, being an extremely important issue in project management. The size of enterprises analyzed is significantly important in the research conducted by its authors; SMEs group, performing a project-driven orders, is particularly at risk of competitive capacity loss, as project management involves application of extensive knowledge, experience, tools and methods and techniques in planning activities in order to reach or to exceed the needs and expectations of employers. This is related to the necessity to combine a lot of parameters, such as, for example: time, cost, requirements and expectations of an ordering party, aims of the project.

A question that therefore appears is: are project teams, which are organized in micro, SMEs for this purpose, able to meet the requirements? Do project managers have proper competencies in the following: knowledge from a given field (I know what), competencies (proceeding knowledge - I know how, and I am able to do it), approach (I know, and I am ready to use my knowledge)? Do the SMEs in Poland use (if so, to what extent) solutions for intelligent organizations and whether the measures improve competitive advantage of the companies (in what areas, if used). Finally, what are the constraints of SMEs sector, in respect of project knowledge management in organization, and what development possibilities for the companies constitute proper solutions for intelligent organizations?

The main purpose of the research is to determine level of project maturity in the Polish SMEs sector, and indicating directions of project management improvement, from the perspective of learning organization features. It is assumed that analyses conducted and conclusions elaborated, shall allow increasing the level of project maturity of the Polish SMEs, by recommending innovative solutions in respect of projects (ventures) execution, and project-driven orders. Context of research directed towards development of learning organization features results from a permanent need to transform enterprises that deal with project management and due to projects transforming from traditional organization into an intelligent one. Processes of generative learning lead to reaching new solutions and facilitate search for new approaches to problems; therefore, they are important also for the development of project maturity of contemporary entities within SMEs sector in Poland.

\section{The core of project management}

Work of modern enterprises in the world economy under globalization process causes that they start directing their work organization towards execution of complex, unique (and frequently innovative) ventures, that is projects. Projects perform an increasingly important function in management of various types of organizations: enterprises, units of state and selfgovernment administration, non-profit organizations, consortia and their presence is noticed in almost every field of human activity (including professional activity, business activity, science, culture, sport, administration), which certainly raises demand for professional knowledge and management abilities within the scope. 


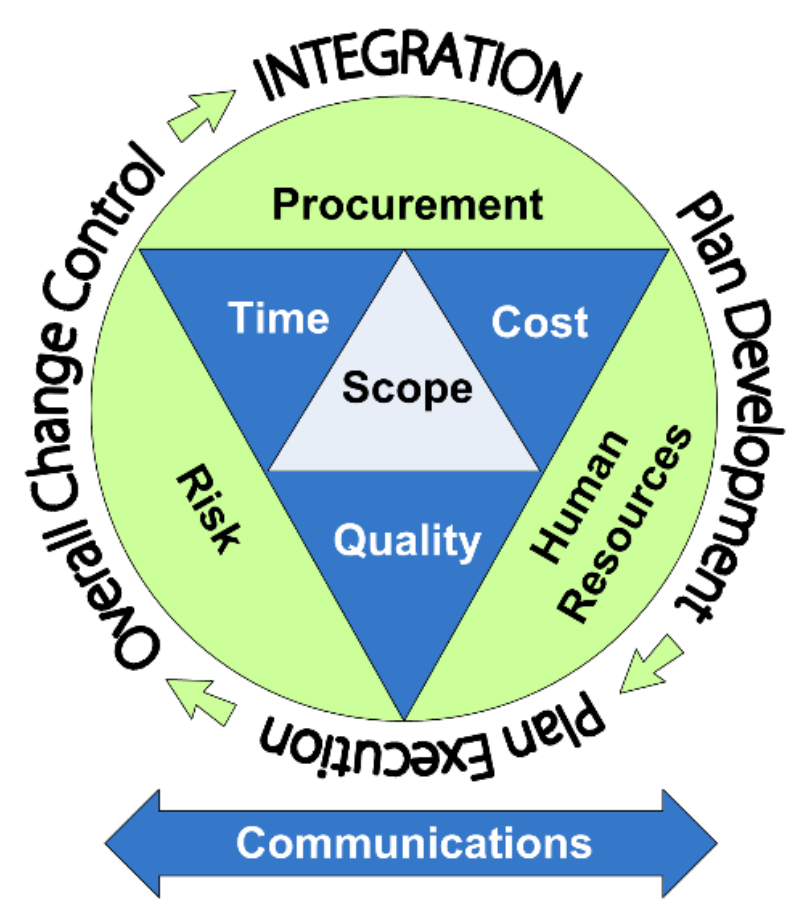

Figure 1. Activities for obtaining project management success (see [2], [18])

Significance of the project issue has been exposed due to the fact of dissemination of the approach to planning within the recent several dozen years, presented by a large group of American organization and management theoreticians, which includes single occasion planning and continuous planning. The definition proposed by the Project Management Institute (PMI) says that "a project is a temporary group activity designed to produce a unique product, service or result".

Project refers to a sequence of unique, complex, and related tasks of various characters with a common aim, to be performed within a specified time, with specified budget, in accordance with requirements established [46]. The purpose of project execution is to reach expected results. In other words, the aim of a project is to reach project parameters at an assumed level, that is, project execution time, project execution cost, and the project performance. Fig. 1 presents basic project parameters, including division of the project into individual stages, which compose into a life cycle: Preliminary stage, intermediate stage - one or a few, final stage with groups of activities under project management (management activities, operation activities, supporting activities).

Project management is based on planning of an activity, organizing, scheduling, monitoring and management of all project aspects, and motivating all its participants with application of respective knowledge, abilities, tools, techniques in order to meet or exceed expected results of a specified venture (project).

Every project has several potential outputs, not all of which are necessarily intentional: 1) a product (or service) delivered for an internal or external customer, and 2) project knowledge related to the product, its production and use:

- technical knowledge concerning the product, its parts and technologies,

- procedural knowledge concerning producing and using of the product and acting in a project,

- organizational knowledge concerning communication and collaboration.

While project organizations have become common, knowledge management of project organizations are still largely underdeveloped. Nevertheless, project organizations require particular systematic and effective knowledge management if they are to avoid knowledge fragmentation and loss of organizational learning.

\section{Characteristics of SMEs sector in Poland}

Experience of highly developed countries shows that small and medium-sized entrepreneurship performs a tremendous role in economy, influencing economic 
growth, better market selection of varied assortment, and helps lower the unemployment rate. SMEs constitute therefore a peculiar stimulus for economy. Their number and potential may be one of the sources of economic growth.

Micro-SMEs constitute a major group of enterprises in the European Union (EU; 99.8\%). An identical situation has been noticed in Poland. Entities of SMEs sector include majority of all active companies out of the number of 1.73 million (99.8\%). However, in comparison with EU average, the sector of SMEs in Poland is more dominated by micro-enterprises, reaching $96 \%$ of the total number of companies (in the EU - 92.3\%). The share of small companies in the group of SMEs in Poland (3\%) is half smaller from the average of EU $-27(6.6 \%)$, whereas the share of medium-sized enterprises in the structure of SMEs is close to EU average (0,9\% - Poland, $1.1 \%$ - EU) [30].

The SMEs sector is the main motor of development of national economy. According to Eurostat, the gross national product (GNP) share of SMEs in Poland is at a level close to an average in EU countries. The latest report of the Polish Agency of Entrepreneurship development indicates that the structure of enterprises share in GNP, every second PLN is generated by SMEs $(47.6 \%)$, whereas the smallest companies generate every third PLN (29.6\%). Share of medium-sized entities is three times smaller $(10.4 \%)$ than the share of micro companies, and the share of small companies is almost four times smaller (7.7\%). In 2010, in relation to 2009 , the share of medium-sized and large enterprises in GNP increased whereas in micro and small enterprises, it decreased [29], [30].

Average trends indicate that the structure of enterprises in Poland slowly progresses towards a drop of share in general number of micro companies (similarly as in the EU). Share of the remaining companies in turn increases. The rate of the transformations indicates that the highest problem with growth and transformation into small entities is experienced by micro-companies [36].

The sector of SMEs is a source of growth and innovation in all industries, opening job opportunities for citizens of a given country. Seven out of ten new jobs are available in SMEs sector in Poland. Employment in the sector of SMEs in the EU constitutes 67\% of employment [34], [29]. SMEs in the world perform a key role in economy shaping. Balanced development of SMEs sector is of essential value for economy and is a necessary condition for economic growth. Companies that are included in the SMEs sector balance negative economic trends, support restructuring of industries, contribute to a high degree to development of global market [1], [5], [10], [19] and [33]. SMEs perform a crucial role in development of innovation to increase competitive capacity, are usually more innovative than large enterprises. This in practice means that innovative activity of the SMEs sector is higher if domination within a given large enterprises is greater. Many enterprises from SMEs sector execute individual client's orders, creating market niches with insignificant turnover and temporary monopolies [24],[44] and [8].

Particular role of SMEs sector results from specific features, which cause that a given enterprise is capable of winning a competitive advantage. One of the most important features of the SMEs sector is their high flexibility and immediate decision making, which is a source of their domination over financially much stronger market opponents. SMEs have got excellent knowledge about local market [6].

The main constraints of SMEs sector companies include lack of sufficient financial resources and resources such as technological resources unlike the large companies, which facilitate a company risk distribution in a portfolio of new products projects and financing of long-term research-development projects [22].

\section{Projects management in SMEs sector}

Typical problem that appears in enterprises, especially in SMEs, is related with undertaking or not undertaking execution of a new order. Specific type of this kind of problems indicates that they should be solved on regular basis. Most of orders obtained by enterprises constitute individual and single orders that require detailed analysis, elaboration of proper management methods. They are therefore frequently treated as project, pursuant to classical PMI definition.

Project management is based on planning of an activity, organizing, scheduling, monitoring and management of all project aspects, and motivating all its participants with application of respective knowledge, abilities, tools, techniques in order to meet or exceed expected results of a specified venture (project). Project management within last three decades experienced significant development, which may be proved by evolution of project management methodology, by the number of project management certification programs, under- 
standing of an impact of project management on general positive result of an organization.

Research on implementation of project management into practice of enterprises, in particular the SMEs becomes particularly important. Research into the status of project management of SMEs sector has been conducted in an insignificant extent.

Owens has conducted research on a selected group of SMEs in Great Britain. The research conducted indicates that most of enterprises questioned, do not implement any standards, techniques, project management tools [25]. Moreover, the enterprises under research do not have any project monitoring or control systems implemented. Organization structures and functions resulting from implementation of projects performed, if available, are not clearly determined.

Tests conducted by Turney's team indicate that SMEs have to individually manage project-driven orders execution and usually it reveals ad hoc activities rather than a systematic collection of methods with cohesive project management approach or a collection of principles that refer to methods of a work execution or proceeding leading to a particular purpose. A high cost of selected project management methodology, implementing trainings and certification, constitutes a barrier impossible to be overcome by SMEs [42]. Research results published by Dziekoński, regarding the project management status in SMEs in Poland indicate low competence of SMEs in project management. SMEs sector entrepreneurs do not apply methods or tools available or they do not understand them [8].

Research conducted by Żmigrodzki [48] refer, among others, to problems of project management in SMEs such as: increasing cost of management of projects under execution, variability of demand, delays in projects execution, conflicts in project group, high number of complaints. Further findings of the author refer to basic features characteristic to project management in SMEs. In SMEs sector project management, it is important to approach the issue in view of the whole enterprise, not only from the point of view of a single project. Formal and informal factors, which as a rule constitute a majority, function independently from project management and have an impact on a project, but not reverse.

\section{$5 \quad$ Knowledge as an attribute of contemporary enterprises success}

By the end of the 20th century, traditional economy distinguished mainly two factors of manufacturing: labor and capital. Knowledge, productivity, education, and intellectual capital was treated as sufficiently available and as a free resource of environment, which did not have to be included in calculations. To a large extent, the basic nature of the world economy has radically changed within recent several dozen years; its currently dominating features include global competition, turbulent variations, faster information flow and higher scope of communication, technological progress, and a growing complexity of business. Currently, knowledge, obtained with awareness, formed and disseminated by means of various methods aimed at shaping proper behavior of employees and development of information technology supporting the processes constitutes the most important strategic resource of an enterprise. Variations taking place in highly developed counties economy have caused, that terms have been used in description of contemporary economy such as "knowledge based economy", "new economy", "information society".

Turbulent variations (technological, social, political, and economic) of the recent years have directed world economy towards a new direction. Economy based on farming and fertile soil, as main factors of countries wealth, mechanical manufacturing using natural resources in excess, as well as energy consuming technological processes being a key to success in economic race of nations has gone to the past. The world entered an era in which ability to obtain and process information and to produce knowledge are becoming the basis for economic success [39].

There are two basic strategies for managing knowledge [15]. The codification strategy is based on codifying the knowledge and storing it in artefacts and databases where it can be accessed. In the personalization strategy, the knowledge is tied to persons who develop it and is shared by personal interaction. As the main focus in knowledge management concentrates on Information and Communications Technology (ICT) tools and explicit knowledge (codification), face-to-face interaction (personalization), needs to be strengthened.

All knowledge, which the mankind disposes of, doubles currently, on average every 5 years. The time of its multiplication becomes regularly shorter. 
At the turn of the 19th and 20th centuries, this time was 50 years [9]. Moreover, an enormous increase in the use of Internet has been recorded within the recent years.

Rich economies, with high level of technological development create information societies, where knowledge management, its quality and rate of flow, constitute basic factors of competitiveness both in the industry and in the services, and the level of development requires application of new techniques, collection, processing, transfer, and use of information.

Digitization of information and permanently growing penetration of all areas of life and labor with new information and communication techniques lead to additional flexibility of structures and jobs. Knowledge, apart from its function as a production factor, is becoming a more and more important subject of production in information society.

Economies based on knowledge and information constitute the most competitive economies in the world, based directly on the production, distribution, and use of knowledge and information [14], [23] and [27]. Highly technological industries perform particular function as knowledge media. Knowledge embodied in new technologies and products within a sector of high technology, and highly qualified resources producing and using the technologies and products decides on innovative character of economy and its modern character and dynamics. As a result, technical-production knowledge included in goods of high level of technological intensity constitutes the main source of growth and competitive advantage [43].

Contemporary scientists do not doubt that the key to success will lie in focusing of effort, on measures and preoccupation with obtaining and keeping in companies persons with unique competencies, lively mind, perfect in action, striving for professional mastery, assuring increase of efficiency mainly by being innovative, thanks to abilities possessed transforming existing resources in new knowledge implemented by means of technology, inventions, products, methods and proceedings [21].

External conditions, such as: ability to use potential opportunities of development, creation of own abilities, predisposition to self-development, and self-education of society become the basis for significant endogenous factors for development (technical progress, development of human capital) of economy. Lack of such conditions or their relative instability increase dispro- portions in development, leading to a relative peripheralization of some economies in relation to other ones in the aspect of competitive advantage [11].

Such situation is a cause of higher demand for a focus of an enterprise on knowledge management processes as a basic concept of managing a modern organization. It integrates processes regarding areas of creativity, innovativeness, contacts with customer, application of the best practices, learning and development of abilities. It also includes aspects of building a culture based on knowledge. Hence, knowledge management is by its nature complex, covering all areas and aspects of organization functioning [37].

Knowledge in activities of an organization, including projects execution, has been for years within the scope of interest of researchers, who confirmed its key significance for construction of permanent competitive advantage of companies and enterprises. In project management, the topic takes a new character as it becomes transferred into a field of dynamic, time-limited, temporary, and team-performed ventures. No extensive research has been conducted in Poland within this field and literature presents the issue rather from theoretical and model perspective than empirical one.

Research conducted in 2011 by Paweł Wyrozębski [45] on a group of over 300 specialists on project management referred to frequency of application of 10 knowledge management practices defined within project activity of Polish organizations. The research clearly indicates that higher the experience and professional achievements of a respondent, the more frequently he/she applied knowledge management and organization good practices in their work. This means, that higher management staff find an important function and task in company functioning and in execution of tasks to be performed. A lot remains to be improved within the aspects. A wrong practice is to leave the field without influence, which constitutes a risk of serious losses for companies. They appear mainly when a person responsible for performance of certain tasks in a project leaves the company, taking his/her knowledge and experience away. Test results obtained indicate that project management is a field that becomes in particular way a beneficiary of knowledge management, creating a new quality, and enriching achievements of both fields [45]. 


\section{Project knowledge management in SMEs - characteristics of initial research}

Research into knowledge management in a life cycle of projects executed by construction engineering companies within the SMEs sector, constitutes a continuation of research performed since 2012 in the Department of Project Management at the Opole University of Technology [26], [20]. The questionnaire research was designed to obtain an answer to the following questions: how entrepreneurs from Opole Province manage projects, what obstacles they find in reaching aims, what is the impact of project engagement on competitiveness of enterprises on market. Twenty five enterprises from the SMEs sector took part in the research, including five micro-companies, twelve small companies, and eight medium companies.

The questionnaire research performed by the authors indicates that most of the enterprises questioned (about $80 \%$ ) do not have an overall approach to project management. Projects undertaken by entrepreneurs are characterized by relatively short execution times, in case of micro-companies (up to 3 months). Projects execution periods, in case of a small and medium-sized enterprise are significantly longer, they are on average 3-6 or 6-9 months long.

As one of the significant areas of knowledge in project management includes human potential use, the authors decided in 2013 to continue the research with the same group of respondents with regard to building of project teams, competencies of their members, function of intellectual capital, and level of knowledge management in projects life cycle.

An important condition, favorable for development and obtaining competitive advantage by knowledge management, is a method of use of human potential. Traditional recruitment of employees becomes obtaining intellectual capital. The most important factor is not the size of an enterprise, but its culture. Employees constitute the most important assets of a company and a process of education has been transformed into education of increase of entrepreneurship [32].

Focus on human capital is conditioned by many variables. From the point of view of the whole economy, investment into human capital depends on globalization processes, transformation, level of economy competitiveness, and its entities that determine in a significant way appreciation of human factor function in economic processes. Company running its activities on the basis of knowledge, should use not only existing knowledge but also aim at its purposeful improvement and complementing [13].

Due to specifics of the research, techniques of uncontrolled observation and free interview have been applied. This allowed better presentation of construction projects execution process, identification of functions of a manager from the point of view of key success factors, and indicating shortcomings in selection of members of project teams. Moreover, it facilitated watching the level of shaping social, organization and technological systems and methods of capitalizing, handing over of useful knowledge regarding project management within the SMEs group under the research.

Projects management is a field where the so-called project management competences models or project managers competencies models can be noticed to become very popular. Organizations responsible for their elaboration and development include usually professional associations such as: Project Management Association (IPMA Competency Baseline), Project Management Institute (Project Manager Competency Development Framework), Engineering Construction Industry Training Board (National Occupational Standards for Project Management), Australian Institute for Project Management (Professional Competency Standards for Project Management).

From the point of view of world standards, the models established so far indicate scope of complex and detailed guidelines, which define elements and levels of project competencies needed and required from organizations and from employees who perform specific roles and functions in specific positions.

Project management practice in SMEs is, however, totally different from standards established. Research conducted so far by the authors indicates that modern SMEs usually do not undertake projects based on analysis of competencies such as: knowledge, abilities, approaches, and behavior of employees obtaining outstanding results. Not many project managers use proper tools and methods of projects management. Level of project maturity of individual companies is very different, and project awareness of construction team members (project teams) is also varied, but is definitely on a low level. 


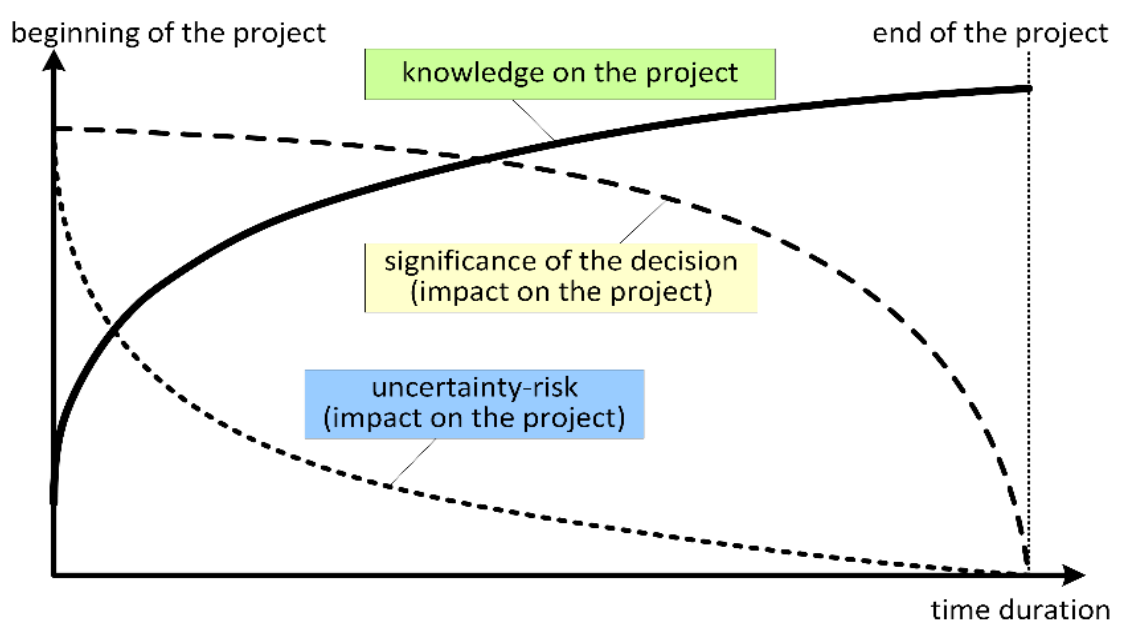

Figure 2. Significance of decision compared to knowledge on project (see [47])

Transformation of project initiative into material results, creating a value for organization within enterprises under research from the construction branch in the SMEs sector is chaotic, in principle, significantly tangential from project-based programs assumed at the beginning, without implemented methods of project management methodologies, and it usually reminds rather ad hoc activities than a systematic collection of methods forming a cohesive approach to project management.

Lack of proper competencies (knowledge, abilities, and attitudes) of project team members, including project managers of projects performed by SMEs, cause significant consequences in reaching (or not) of the project purpose, within a specific time, at planned cost and of required quality.

Exceeding a directive deadline for project execution appears in each of the enterprises under research. Financial penalties imposed by the contractors constitute a consequence of exceeding the directive deadline in medium-sized enterprise. Micro and small enterprises usually negotiate extension of execution time with contractors, which lowers their reliability viewed by customers, loss of next orders of a given customer. In relation to cost management, the research indicates mainly weak points of practice in project approach of the enterprises under research. Most of enterprises under research do not apply sufficient project calculation, which results measurably in exceeding the planned budget level.

The entrepreneurs asked indicated that at estimating of time and cost of individual tasks in the project, they do not use knowledge or experience of employees working at previous projects (almost 80\%). They do not use any formal methods, time estimation tools, or project execution cost calculation $(67 \%$ of micro and small enterprises).

Main conclusion of the observations and analyses above is the fact that, in particular, the SMEs need competent project managers, who will be able to manage efficiently, and manage execution: introduce organization variations and new technologies, implement strategic development projects, hand over construction objects on time, pursuant to budget and quality requirements.

Moreover, specifics of contemporary entities of the SMEs sector should be associated with learning organization, organization oriented into permanent obtaining, transforming, and popularizing of knowledge on markets, products, technologies, and processes. Interference of events, phenomena, and processes inside and outside organizations gradually displaces process individuality in business activity. Economy transmigration towards chaos, unpredictability, and a phenomenon of uncontrolled dynamics causes also that SMEs apply institutional mechanisms of learning and their introduction as a permanent element of project organization culture.

\section{$7 \quad$ Knowledge management in the project life cycle}

Project management is a management field that deals with application of knowledge available, abilities, tools, and techniques in order to meet demand and expectations of projects clients. 


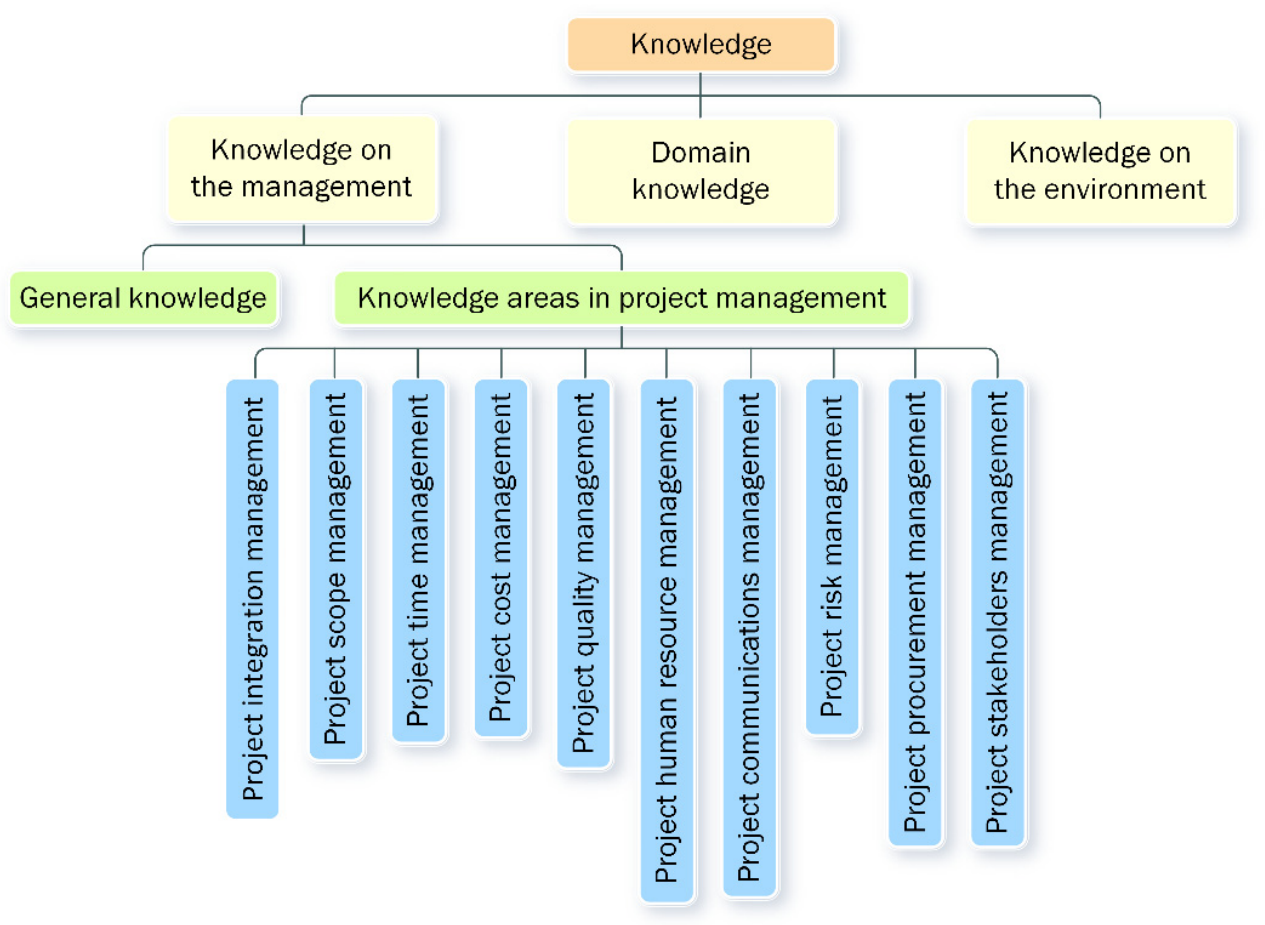

Figure 3. Kinds of knowledge required for projects (see [12], [2]])

Pursuant to the definition, project knowledge may be considered a useful information resource facilitating projects execution pursuant to time, cost, and results quality aims.

Projects nature involves particular dependency, which is not directly described by project management standards, but is accentuated in the background. Significance of decisions and its impact on project is, in principle, inversely proportional to the project knowledge possessed, both at the beginning and at the end of a project (see Fig. 2).

Existence of the relationship influences the whole structure of methods and processes of project management starting from baseline elaboration, through progressive planning, staging, and risk management to post-project reports [47].

Projects are characterized by a high level of uncertainty at the beginning of their execution. It results from one of the project definition features - providing of a novelty, hence with significant amount of unawareness burden. A project is executed progressively by means of subsequent approximations. If there are so many unknown data, any initial estimates and assumptions may turn out untrue, that is, a task may take not one day or a week, a product may cost twice as much, new technology will be much more efficient than assumed and a new supplier turn out unreliable.

Knowledge at the end of a project in turn, when everything that was incorrect and correct had already happened, is a complete knowledge. Actual task times are known, cost of the project is known, it is known whether the customer is satisfied, weak and strong points of project teams, etc. are known. Throughout project life cycle, knowledge about it grows from almost zero to agreed level of $100 \%$. At the beginning of a project, managers are at the same time forced to make the most important decisions. This involves existence of a serious paradox - the most important and the greatest number of decisions have to be made at the moment of the highest risk.

Knowledge necessary in a project includes various areas (see Fig. 3 and [47]):

- knowledge on competencies and attitudes of project team,

- knowledge about approach and aims of project parties,

- knowledge about technology, chances, and difficulties related thereto,

- knowledge about business situation of customer or a supplier, 


\section{EFFECTIVENESS}

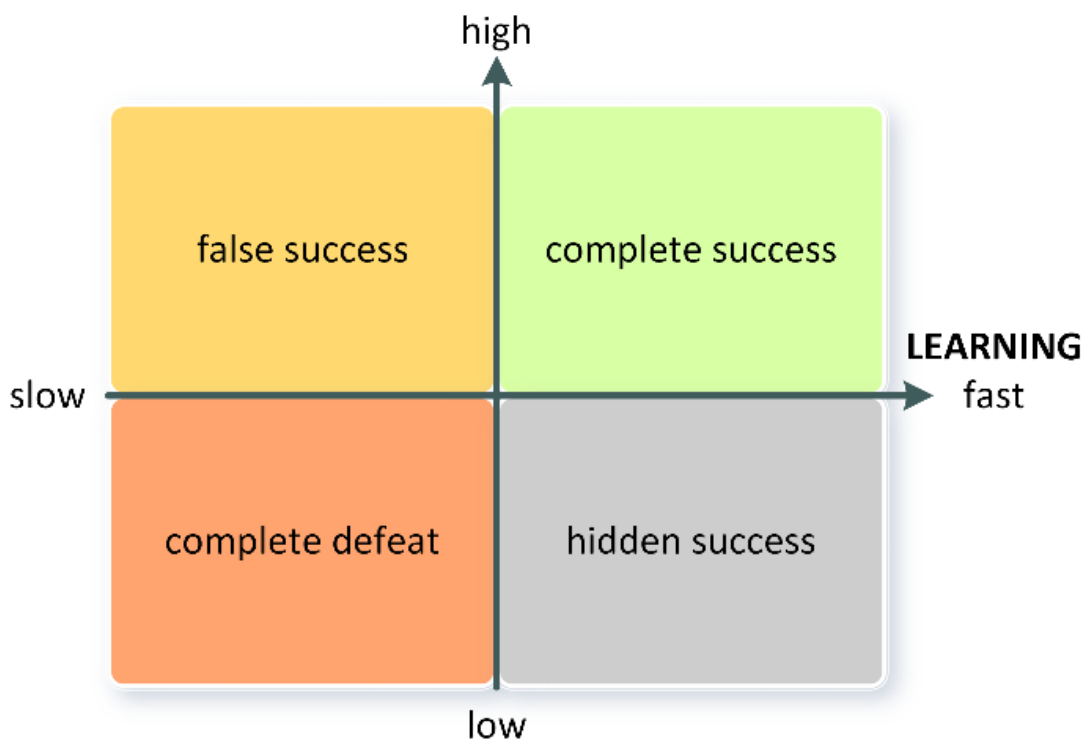

Figure 4. Project success-extended overview (see [3])

- knowledge about other projects under execution in an organization,

- knowledge about business and production processes and office works related thereto,

- knowledge about natural or legal environment in which the project is performed.

Damm and Schindler [7] distinguish in turn, knowledge about projects, knowledge in projects, and knowledge from projects. It is related with the process of learning during execution of each project. Knowledge and experience gained in this way may be treated as accumulative intellectual capital of an organization and as one of important project success factors (see Fig. 4).

Project organizations have tremendous possibilities of learning at projects [35], they are therefore considered intensely learning organizations. Frequently, however, measures taken by them do not confirm the assumptions. The end of a project is usually associated with exhaustion of learning possibility, and the effects of learning under one project are not transferred further to others and become forgotten. For a project-type organization, it involves high cost of lost possibilities to improve project management techniques and methods. Organizations may and should learn from projects, by use of knowledge resources collected and by creating opportunities for concluding from measures taken and their effects on employees [17]. A condition for use and application of knowledge is to collect it and make it available to all employees.
Fig. 5 presents a situation when project team may use organization knowledge (blue line) collected also at previous projects. PMBOK guide characterizes it in general: Organizational Process Assets, that is an intellectual capital of a company. Difference between traditional situation and possibility to use additional know-how constitutes just a start-up from a better position for a project team, that is, at a higher level of knowledge about a future project. For example, if a database of suppliers is available, it is known who should be avoided during a tender; if a database of task times is available, it is possible to evaluate efficiency of people and reliability of their forecasts [47].

One of the management aims is to expedite project knowledge increase so as to reduce area of uncertainty as much as possible or to postpone risk decisions in time. The learning curve should therefore be as convex to the top as possible, which is presented in Fig. 5 by a green line.

During a project, it is possible to learn faster or slower. It is, for example, possible to wait for weeks for a result of a large package of works executed through outsourcing, and notice at the end that a contractor was incompetent. Work could also be divided into small packages, a regular inspection at a contractor's could be introduced and a reaction thereto at the very beginning applied, when problems are noticed. 


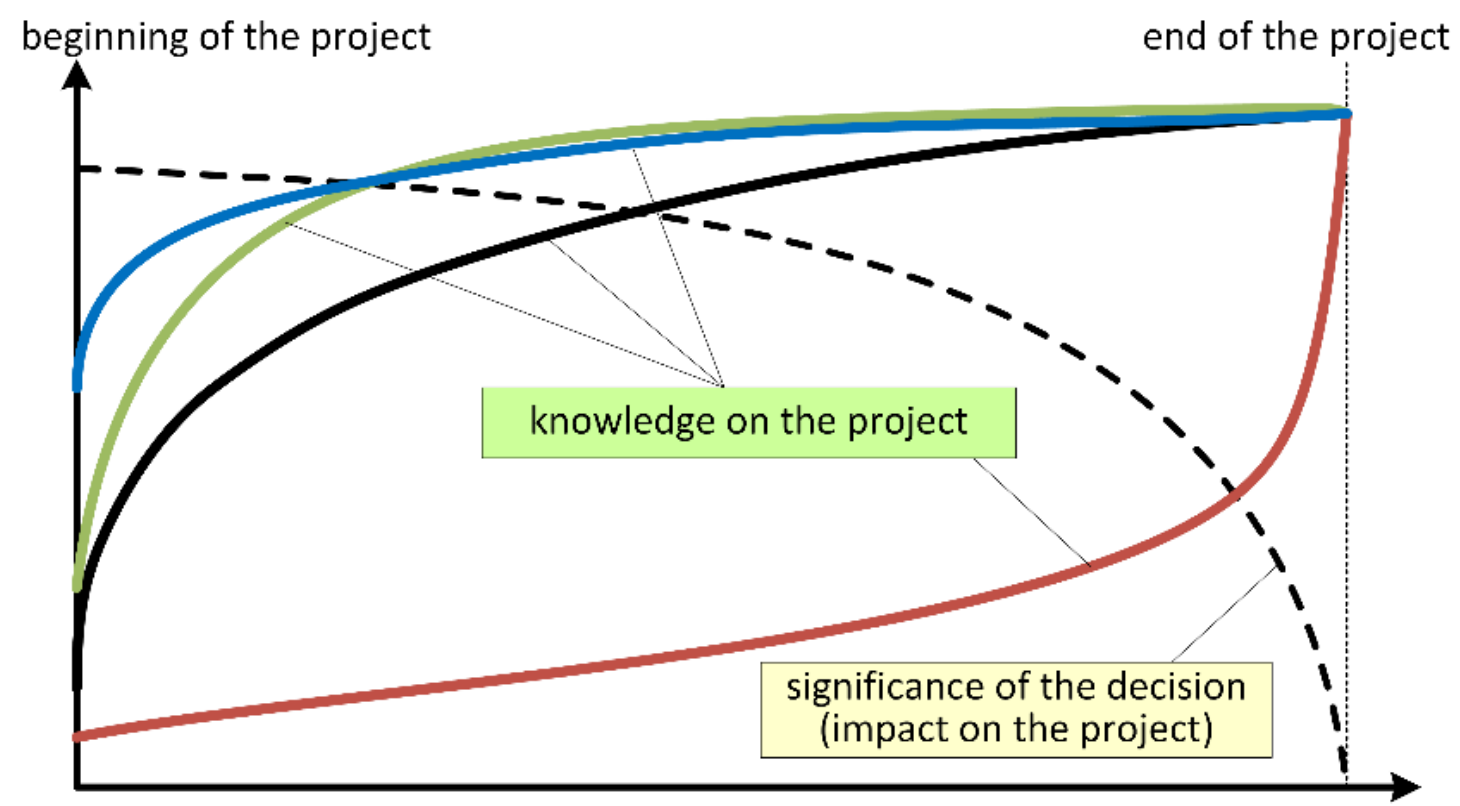

time duration

Figure 5. Significance of decisions compared to project knowledge supported with knowledge about organization (see [47])

The main problem is to run projects in chaotic manner, when project team has not agreed complex requirements, concepts, or scope, which causes conflicts and problems; project knowledge will be collected extremely slowly (red line in Fig. 5) [47]. It is better to run incorrectly a well-planned project than to execute well an incorrectly planned project (a paradox resulting from Murphy's laws).

One of the main challenges of project management is the minor and tangled accumulation of knowledge. The content and quality of the knowledge created vary, as well as the ability of organizations to utilize it. In this study, knowledge management in a project is considered to consist of four groups of activities: (1) knowledge creation, for example, collection, combination, and refinement, (2) knowledge administration, for example, storage, organization, and retrieval, (3) knowledge dissemination within and outside the project, and (4) knowledge utilization and productization, for example, integration into products and decisions, and application in other projects.

\section{Quality research results - exploration stage}

A literature analysis of issues and quality research has been conducted under the research on project organizations intelligence within SMEs sector (exploratory stage). Quantity research is in progress (diagnostic stage). The crucial aim of quality research was an attempt to explain and understand phenomena related to project organization functioning in the context of generative learning processes, including causes and rules that govern them. Exploration research was conducted in September - November 2013. Twentyfive extended individual interviews in construction industry enterprises of SMEs in Opole Province have been carried out under quality research. Moreover, four main areas of good practices of SMEs as intelligent organizations managing project-driven orders were identified and elaborated within the quality research. Diagnostic stage will constitute crucial part of the research. It will include quality research, which will be performed from January to June 2014. It will be performed by means of direct questionnaire interviews using a paper questionnaire (PAPI). Quantity research shall be performed on a sample of about 100 micro, small, and medium enterprises that perform projectdriven orders.

For the needs of the research, a definition of intelligent organization was adopted, which implies that a project organization modifies its behaviors, according to knowledge obtained and variations in external environment. Due to the fact that it involves specialized processes related to creating, shaping, and transfer of project knowledge, learning by its all members, in particular, by project teams, becomes easier. 
It was, moreover, assumed that a project-intelligent organization is an organization that performs the following activities: (1) systematic problem solving in projects, (2) experimenting (regular research, testing of new knowledge, search for new methods of problem solving), (3) learning on the basis of previously gained experience during execution of projects, (4) learning from others (including benchmarking), (5) capitalization of project knowledge, (6) transfer of knowledge by organization in a fast and efficient manner.

The purpose of information analysis obtained in individual interviews with management staff of the SMEs sector entities that execute project-driven orders consisted in obtaining identification and description of: (1) external and internal factors, which contribute to learning and elements of project knowledge management strategy in intelligent enterprises of SMEs sector, in construction engineering industry, (2) methods of human resources management and a required competencies profile of a manager/member of project team in intelligent enterprises of SMEs sector, (3) competitiveness factors, constraints, and development requirements of intelligent entities within SMEs sector, which execute project-driven orders.

The research conducted implies that characteristics of projects which differentiate them from routine activities of enterprises cause, that project management is definitely more difficult than knowledge management in traditional organizations (in particular, for SMEs), but it also may bring potentially higher advantages. Two basic features of projects, identified mainly with drawbacks in project knowledge management, include project time limiting and its unique character. Projects' uniqueness results not only from unique aims of projects but also from other causes. Projects constitute activities being directed towards a short-term cooperation of interdisciplinary teams formed by internal and external experts for an organization, and they constitute unique groups of employees. Hence, specifying three main project parameters - time, cost, and resources, constitutes a serious constraint for project knowledge management.

Due to time limiting, the SMEs under research indicated lack of time to collect valuable project knowledge. Additionally, because of human nature features, project team members are reluctant to consider defeats and incorrect project execution decisions, which might frequently constitute a valuable source of knowledge. Moreover, frequently, knowledge collected during project execution disappears, especially in SMEs, when a project team, that is organization structure employed in project purpose execution becomes disintegrated, and individual persons come back to work in organization departments. Due to lack of further project meetings, teams existing continually in traditional organizations become disintegrated. Even project documentation (especially in SMEs), which may constitute a source of project knowledge, is located in a rather unknown location and is not available for those who would like to use knowledge and experience of others.

Worth noting is the fact that an increase in project activity of organizations results in various effects. It involves not only decentralisation of organization structure but also segmentation of organization knowledge. SMEs sector project organizations usually do not have structures that collect and store knowledge in traditional organizations. In projects, it is, however, important that knowledge and skills obtained during execution are collected and archived in an organization in a manner, which is available for all subsequent members of projects execution. It implies that SMEs working on project-driven basis or by project-driven orders that do not collect project knowledge, suffer greatest losses, due to tremendous potential and opportunities in obtaining project knowledge and its use, its application and implementing in subsequent projects.

Project organizations, including SMEs, frequently execute several projects/project-driven orders simultaneously, which causes that knowledge management is even more difficult but potentially more advantageous. Traditional project management focuses on activities such as planning, organizing, management, and control of resources directed towards execution of the project aim within time scheduled and within a specified budget.

This indicates that in traditional project management, the work of a project team must be efficient and effective, and to guarantee its execution in this manner, it is necessary to introduce knowledge management processes within an organization, which are rarely executed in project-type organizations. SMEs make expensive investments into improvement of project works under execution, but hardly ever invest in projects evaluation, which obstructs learning from them. The following problems related to analysis after a project have been identified (lesson learned): people do not remember what happened in initial stages of a project, they go to 
other projects and it is difficult to collect them for a review, there is no time or money in a project for reviews, company management's main interest is focused on effects of a project not on knowledge collection.

Its conclusion is that in the best case, project knowledge constitutes an individual knowledge resource of individual organization members, to be used by them in the future.

Luckily, an increase in project manager's awareness regarding necessity to manage project knowledge caused intensification of and an attempt to systematize organization measures within this scope. Interviews frequently focus on indicating the necessity to increase project organization intellectual capital by: improvement of knowledge of individual employees (trainings, courses, etc.), intensifying cooperation within project teams (inside, and between them), increase of knowledge transfer between employees (communication). All initiatives undertaken are worth noting, but frequently, activities only, their quality and effects are far from an ideal, which causes why SMEs sector organizations do not use the potential offered by organization and project knowledge.

\section{Summary}

To summarize quality research results obtained from entities of SMEs sector, it should be emphasized that there is certainly a low level of project-driven orders execution solutions implementing, proper for intelligent organizations. It is compliant with the hypothesis assumed, that the key problem in projects execution is an improper management of project knowledge, revealed by low efficiency of its use, and mainly a weak ability of organizations to accumulate project knowledge and loss of organization memory.

The phenomena result in an insignificant efficiency of projects, low quality of results, dissatisfaction of project employers, and ineffective management of resources designed for their execution. Weak level of organizations learning and use of project experience leads to an unwillingness towards execution of innovative projects, and as a result, to a loss of chances - not only from the point of view of business activity but also of the social and macroeconomic ones.

To improve the situation the following recommendations were indicated, in individual interviews with management members of SMEs sector: (1) documenta- tion of the knowledge obtained in projects, at best on a regular basis, (2) generating employment and cooperation conditions that support knowledge exchange, (3) maintaining of organization knowledge map, (4) search for knowledge existing within an organization, before "wheel starts being invented" again. The instructions listed, directly influence project management, which in its essence is related to knowledge processing. Project team members, who have specialist knowledge - work together under a project, to supply new products and services on time, according to budget and specified quality criteria. From this point of view, it is important for a project manager to manage knowledge of its own team and interested parties he/she should integrate it as much as possible to facilitate execution of a project in a successful manner. Project team members, also manage their knowledge individually and in a team - using the possessed knowledge and attaining new knowledge, handing it over to others, and creating together new knowledge within an organization. Application of knowledge management methods in projects execution is therefore significantly substantiated in order to guarantee success in ventures executed.

Knowledge-based economy opens new challenge for enterprises, in efficient and effective development of organization-learning processes. The research conducted indicates, that the level of progress of SMEs sector entities in adjustment to current economic challenges is still quite low. This is indicated by quality research results, and preliminary estimates for quality research assume confirmation of the hypothesis concerning the assumed index at a level of about $12 \%-$ only less than every eighth enterprise executing project-driven orders may be specified as an entity with features of an intelligent organization.

\section{References}

[1] Acedo F., Florin J. - An entrepreneurial cognition perspective on the internationalization of SMEs [in] Journal of International Entrepreneurship, Vol. 4, No. 1, 2006, pp. 49-67.

[2] A Guide to the Project Management Body of Knowledge. Fifth Edition. PMI, USA 2012.

[3] Arthur M.B., DeFillippi R.J., Jones C. - Projectbased learning as the interplay of career and company non-financial capital [in] Management Learning, No. 32 (1), 2001, pp. 99-117. 
[4] Atkinson R. - Project management: cost, time and quality, two best guesses and a phenomenon, it's time to accept other success criteria [in] International Journal of Project Management, Vol. 17, No. 6, 1999, pp. 337-342.

[5] Audretsch D. - Research issues relating to structure, competition, and performance of small technology-based firms [in] Small Business Economics, Vol. 16, No. 1, 2001, pp. 37-51.

[6] Bogdanienko J. - Możliwości zwiększania innowacyjności matych i średnich firm $w$ warunkach globalnej konkurencji (Opportunities for increasing the innovativeness of small and mediumsized businesses in a global competition) [in] Problemy Zarzadzania, No. 4, 2007, pp. 74-94.

[7] Damm D., Schindler M. - Security issues of a knowledge medium for distributed project work [in] International Journal of Project Management, No. 20, 2002, pp. 30-47.

[8] Dziekoński K. - Zarzqdzanie projektami w małych $i$ średnich przedsiębiorstwach (Project management in small and medium-sized enterprises) [in] Ekonomia i Zarzqdzanie, No. 4, 2010, pp. 97-104.

[9] Fic M. - Gospodarka oparta na wiedzy (Knowledge-based economy) [in] Teoretyczne aspekty gospodarowania (ed. D. Kopycińska). Katedra Mikroekonomii Uniwersytetu Szczecińskiego, Szczecin 2005, p. 95.

[10] Floyd D., McManus J. - The role of SMES in improving the competitive position of the European Union [in] European Business Review, Vol. 7, No. 2, 2005, pp. 144-150.

[11] Gardocka-Jałowiec A. - Kapitat społeczny jako deskryptor przewagi konkurencyjnej (Social capital as a descriptor of competitive advantage) [in] Przedsiębiorstwo i państwo - wybrane problemy konkurencyjności (ed. T. Bernat). Katedra Mikroekonomii Uniwersytetu Szczecińskiego, Szczecin 2007, p. 181.

[12] Gasik S. - Zarzadzanie wiedza o projektach (Knowledge management about the projects) [at] Seminarium PMI Warsaw Branch, Warszawa 2010 .

[13] Grant R.M. - The resource-based strategy of competitive advantage: implications for strategy formulation [in] California Management Review, No. 3, 1991, p. 115.
[14] Grudzewski W.M., Hejduk I.K. - Zarzqdzanie wiedzq $w$ przedsiębiorstwach (Knowledge management in enterprises). Difin, Warszawa 2004.

[15] Hansen M.T, Nohria N, Tierney T. - What's your strategy for managing knowledge? [in] Harvard Business Review, Vol. 77, No. 4, 1999, pp. 106116.

[16] Kisielnicki J. - Zarzqdzanie projektami. Ludzie procedury - wyniki (Project management. People procedures - results). Oficyna a Wolters Kluwer business, Warszawa 2011.

[17] Klincewicz K. - Cele zarzqdzania wiedza (The objectives of knowledge management) [in] Zarzqdzanie wiedzq (eds. D. Jemielniak i A.K. Koźmiński). Wyd. Akademickie i Profesjonalne, Warszawa 2008, pp. 77-114.

[18] Lock D. - Project management. Ninth Edition. Gower Publishing Ltd, Hampshire, Great Britain 2009.

[19] Low D., Chapman, R. - Inter-relationships between innovation and market orientation of SMEs [in] Management Research News, Vol. 30, No. 12, 2007, pp. 878-891.

[20] Łapuńka I., Biniasz D. - Badanie kompetencji menedżerów projektów $w$ przedsiębiorstwach budowlanych (Competency study of project managers in construction companies) [in] Przedsiębiorczość i Zarzadzanie, Tom XIV, Zeszyt 12, Część II, 2013, pp. 101-111.

[21] Morawski M. - Zarzadzanie wiedza w perspektywie personalnej (Knowledge management in the perspective of personal) [in] Zarzqdzanie wiedza $w$ przedsiębiorstwie (ed. K. Perechuda). Wydawnictwo Naukowe PWN, Warszawa 2005, p. 205.

[22] Murphy A., Ledwith A. - Project management tools and techniques in high-technology SMEs [in] Management Research News, Vol. 30, No. 2, 2007, pp. 153-166.

[23] Nonaka I., Takeuchi H. - Kreowanie wiedzy w organizacji (The Knowlegde Creating Company). Poltext, Warszawa 2000.

[24] Noteboom B. - Innovation and diffusion in small firm: theory and evidence [in] Small Business Economics, No. 6, 1994, pp. 327-347. 
[25] Owens J.D. - Why do some UK SMEs still find the implementation of a new product development process problematic? An explanatory investigation [in] Management Decision, Vol. 45, No. 2, 2006, pp. 235-251.

[26] Pisz I., Łapuńka I. - Zarzqdzanie projektami $w$ matych $i$ średnich przedsiębiorstwach - wyniki badań (Project management in small and mediumsized enterprises - research results) [in] Gospodarka Materiałowa i Logistyka, No. 7, 2012, pp. 1622.

[27] Porter M.E. - Porter o konkurencji (Porter about competition). PWE, Warszawa 2001.

[28] Probst G., Raub S., Romhardt K. - Zarzadzanie wiedza $w$ organizacji (Knowledge management in the organization). Oficyna Ekonomiczna, Kraków 2002.

[29] Raport o stanie sektora matych i średnich przedsiębiorstw $w$ Polsce (The report on the state of small and medium-sized enterprises sector in Poland) (eds. A. Brussa, A. Tarnawa). PARP, Warszawa 2011.

[30] Raport o stanie sektora matych i średnich przedsiębiorstw $w$ Polsce $w$ latach 2010-2011 (The report on the state of small and medium-sized enterprises sector in Poland in 2010-2011) (eds. A. Tarnawa, P. Zadura-Lichota). PARP, Warszawa 2012.

[31] Reich A.H., Wee Y.S. - Searching for knowledge in the PMBOK Guide [in] Project Management Journal, Vol. 37, No. 2, 2006, pp. 11-26.

[32] Sajkiewicz A. - Zarzqdzanie kapitałem ludzkim a przedsiębiorczość - wyzwania XXI wieku (Management of human capital and entrepreneurship challenges the twenty-first century) [in] Kapitat ludzki a kształtowanie przedsiębiorczości (ed. M. Juchnowicz). Poltext, Warszawa 2004, p. 17.

[33] Salvato C., Lassini U., Wiklund J. - Dynamics of external growth in SMEs: Process of model acquisition capabilities emergence [in] Schmale-bach Business Review, Vol. 59, No. 3, 2007, pp. 282305.

[34] SBA Fact Sheet 2012: Enterprise and Industry Poland. Komisja Europejska, Bruksela 2012.

[35] Sense A., Antoni M. - Exploring the politics of project learning [in] International Journal of Project Management, No. 21, 2003, pp. 487494.
[36] Soroka H. - Rozwój przedsiębiorstw sektora MSP $w$ Polsce $i$ znaczenie kredytu handlowego $w$ ich funkcjonowaniu (The development of the SMEs sector in Poland and the importance of trade credit in their functioning) [in] Nauka dla gospodarki. Ekonomia i Zarzqdzanie (ed. C.F. Hales). Uniwersytet Rzeszowski, Rzeszów 2010, pp. 201-209.

[37] Szarafin M. - Knowledge management: słowo (przed)wstępne (Knowledge management: preface) [in] Problemy Jakości, No. 3, 1999, pp. 11-14.

[38] Szpitter A.A. - Innowacyjne podejście do zarzadzania projektami (Innovative approach to project management) [in] Przeglad Organizacji, No. 1, 2012, pp. 10-13.

[39] Toffler A. - Trzecia fala (The Third Wave). Wydawnictwo Kurpisz, Poznań 2006.

[40] Trocki M. - Podstawy zarzadzania projektami (Fundamentals of project management) [in] Zarzadzanie projektami (ed. M. Trocki). Polskie Wydawnictwo Ekonomiczne, Warszawa 2003, pp. 13-33.

[41] Turban E., Meredith J.R. - Fundamentals of Management Science. Irwin, Boston, Homewood 1991.

[42] Turney J.R., Ledwith A., Kelly J. - Project management in small to medium-sized enterprises. A comparison between firms by size and industry [in] International Journal of Managing Projects in Business, Vol. 2, No. 2, 2009, pp. 282-296.

[43] Turowski K. - Sektor wysokiej techniki jako czynnik rozwoju kapitatu ludzkiego - implikacje dla konkurencyjności polskiej gospodarki (High-tech sector as a factor in the development of human capital - implications for the competitiveness of the Polish economy) [in] Kapitat ludzki w gospodarce opartej na wiedzy (ed. D. Kopycińska). PrintGroup, Szczecin 2006, p. 94.Von Dran G., Kappelman L., Prybutok V. - Empowerment and the management of an organizational transformation project [in] Project Management Journal, Vol. 27, No. 1, 1996, pp. 12-17.

[44] Woloński R. - Rola wiedzy $i$ innowacji w rozwoju małych $i$ średnich przedsiębiorstw - przeglad dotychczasowych badan (The role of knowledge and innovation in the development of small and medium-sized enterprises - a review of existing research) [in] Problemy Zarzadzania, No. 4, 2007, pp. $128-155$ 
[45] Wyrozębski P. - Praktyki zarzqdzania wiedza projektowa $w$ polskich organizacjach - wyniki badań (Knowledge management practices on the project in Polish organizations - research results) [in] Ementor, Vol. 42, No. 5, 2011.

[46] Wysocki R.K., McGary R. - Efektywne zarzadzanie projektami (Effective project management). Helion, Warszawa 2005.

[47] Żmigrodzki M. - Wiedza w cyklu życia projektu, czyli o czym PMBOK nie wspomina (Knowledge in the project life cycle, what the PMBOK does not mention). 4pm.pl Project Management, www.4pm.pl/artykuly/wiedza-w-cyklu-zyciaprojektu-czyli-o-czym-pmbok-nie-wspomina (accessed on 2013.11.15).

[48] Żmigrodzki M. - Zarzadzanie portfelem projektów: matymi kroczkami (Project portfolio management: small steps). Octigo sp. z o.o., www.octigo.pl (accessed on 2012.04.23). 